\title{
GEOPHYSICAL CHARACTERISTICS OF EPIKARST: CASE STUDIES FROM ZAGROS MTS. (IRAN) AND THE KONĚPRUSY REGION (CZECH REPUBLIC)
}

\author{
GEOFIZIKALNE ZNAČILNOSTI EPIKRASA: \\ PRIMERJALNA ŠTUDIJA GOROVJA ZAGROS (IRAN) \\ IN PODROČJE KONĚPRUSY (ČEŠKA REPUBLIKA)
}

PAVEL BOSÁK ${ }^{1} \&$ VOJTĚCH BENEŠ²

${ }^{1}$ Institute of Geology, Academy of Sciences of the Czech Republic, Rozvojová 135, 16502 Praha 6, Czech Republic, e-mail: bosak@gli.cas.cz

${ }^{2}$ G-Impuls Ltd., Př́stavní 24, 17000 Praha 7, Czech Republic 
Pavel Bosák \& Vojtěch Beneš: Geophysical characteristics of epikarst: case studies from Zagros Mts. (Iran) and the Koněprusy region (Czech Republic)

Characteristics of epikarst zone were studied by geophysical methods, especially refraction seismics, combined with electrical resistivity and gravimetry measurements. Applied methods were equal in both regions, so comparable results were obtained. The interpreted seismic boundaries follow the basal plane of epikarst (s.l.) and limit the epikarst zone from the geophysical point of view, i.e. zone with comparably low seismic velocities (mostly 1,000 to 3,000 m.s. $\mathrm{s}^{-1}$ ). The thickness of epikarst in the Czech Karst - the Koněprusy Devonian - is from 5 to about $60 \mathrm{~m}$. The epikarst in Zagros Mts. reached up to $180 \mathrm{~m}$ (Cretaceous lmst.). The differences of character and vertical extent of epikarst zone depend on entirely different geological structure and geomorphological setting (relief) and evolution of both sites, which established different conditions for the release of residual stress in the limestone massifs.

Key words: epikarst, refraction seismics, Zagros Mts., Koněprusy Devonian, Islamic Republic of Iran, Czech Republic.

Izvleček

UDK: 551.44(55+437.1)

Pavel Bosak \& Vojtěch Beneš: Geofizikalne značilnosti epikrasa: primerjalna študija gorovja Zagros (Iran) in področje Koněprusy (Češka republika)

Značilnosti epikraške cone so bile preučevane s pomočjo geofizičnih metod, posebej s pomočjo refrakcijske seizmike, kombinirane z električno upornostjo in gravimetrijskimi meritvami. Enake metode so bile uporabljane na obeh področjih, kar omogoča primerljive izsledke. Interpretirane seizmične meje sledijo bazno ploskev epikrasa in z geofizičnega stališča omejujejo epikraško cono, to je cono s primerljivimi nizkimi seizmičnimi hitrostmi (najbolj pogosto 1000 do $3000 \mathrm{~m} \mathrm{~s}^{-1}$ ). Na Češkem, na devonskem področju Koněprusy, je debelina epikraške cone 5 do $60 \mathrm{~m}$. Epikras v gorovju Zagors pa dosega debelino $180 \mathrm{~m}$ (kredni apnenci). Razlike v značaju in debelini epikraške cone so v celoti odvisne od geološke zgradbe in geomorfoloških danosti (reliefa) ter od razvoja obeh področij, v čemer je vzrok različnih mo•nosti sproščanja nekdanjih pritiskov v apniških pogorjih.

Ključne besede: epikras, refrakcijska seizmika, Zagros, devonski Koněprusy, Iran, Češka. 


\section{INTRODUCTION}

The application of a complex of geophysical methods for geological exploration reasons on two geomorphologically different places offers the possibility of mutual comparison. The Iranian site, Mollasadra Dam site project, is situated in very young geomorphological setting, where the youngest phase of the Zagros orogeny has been continuing since Miocene (Nowroozi 1972; Bosák et al. 1998) producing typical high mountain morphology with substantial altitude differences. On the other hand, the Koněprusy region is situated on a stable and intensively planated epi-Variscan platform with only minor neotectonic movements since the principal (Variscan) orogeny and low altitude differences ( $c f$. Bosák 1997b).

The complex of geophysical exploration methods included refraction seismics, gravimetry and microgravimetry, electric resistivity and electric vertical sounding. Refraction seismic measurements along regional profiles offered both the adequate depth penetration and the best view of physical properties of a nearsurface layer of limestones (epikarst s.l.).

\section{CASE STUDY 1 - MOLLASADRA DAM}

The site is located in south-central Iran about $120 \mathrm{~km}$ NNW of city of Shiraz and $8 \mathrm{~km} \mathrm{~S}$ of Sedeh village (coordinates: about 3,391,000/601,500 and 3,389,000/604,500; Fig. 1). Geophysical measurements were carried out to detect geological structure for the construction of water power station. The station was planned to utilise hydraulic head resulting from a dam on the eastern side of a mountain and the power station located deeply on plains at the western foot of the mountain. The mountain ridge should be crossed by a tunnel.

\section{Geography and geology}

The highest summit of the anticlinal mountain ridge is at $3160 \mathrm{~m}$ a.s.l. The explored site at about 2050 to $2250 \mathrm{~m}$ a.s.l. is entrenched by a deep canyon-like valley to gorge with very steep slopes.

The mountain range represents brachyanticline elongated in a Zagros trend (NW-SE) plunging towards the NW under the cover of coarse clastic Bakhtyari Formation (Pliocene-Pleitocene) and Quaternary alluvial and deluvial deposits filling the synclinal structures. The anticline core is built of complex alternation of limestones and marls belonging to Cretaceous Bangestan Group (Albian to Campanian). Compact limestones of varied lithology dominate in the core of the anticline with up to $5 \mathrm{~m}$ thick beds (about $80 \%$ of the section). Clayey limestones form interlayers in compact limestones 0.1 to $0.2 \mathrm{~m}$ thick (about $15 \%$ ). Flanks of anticlines contain also marsltone interlayers with the maximum thickness of $1 \mathrm{~m}(5 \%)$. The section can be compared with Sarvak, Surgah and Ilam Formations ( $c f$. Huber 1977; Setudehnia 1977). Sarvak Formation is known as feature-forming rock unit (Huber 1977; Bosák et al. 1998). Except of summit part of studied sections, limestones are covered by Quaternary unconsolidated sediments (various types of gravels) and also by some lithified conglomerates.

The NW plunge of the anticline has an anticlinorium character with some smaller anticlines of the NNW-SSE direction. The prevalent structural lines have NNW-SSE trend, oblique to main fold axis trend. The W-E trending faults and fissures predispose some morphological features (e.g., the erosional cut of the canyon). 


\section{Method of seismic measurement}

The refraction seismic measurements along up to $1,000 \mathrm{~m}$ long profiles followed the axis of the planned tunnel. The seismic waves were induced by blasting. The distance of geophones was $20 \mathrm{~m}$. The 48 channel apparatus (OYO Seis 1600) was used. The data were processed by the $t_{0}$ method (Hagivar's method). The output is represented by cross sections with refraction boundaries and graphs of limit seismic velocities.

\section{Description of typical cross sections}

Cross section No. 1 (Fig. 2) was situated at the southern margin of a canyon. There are one to two seismic boundaries. The shallow one can be interpreted only in places. It represents the thickness of Quaternary cover. The seismic velocities within the cover are 500 to $1,000 \mathrm{~m} . \mathrm{s}^{-1}$. The second boundary can be interpreted as limit of karstification in limestones. The average thickness of that layer is $81 \mathrm{~m}$, the maximum one up to $176 \mathrm{~m}$. Seismic velocities of karstified limestones is from 2,000 up to 4,000 m.s. $\mathrm{s}^{-1}$. Limestones with weak karstification show velocities over 4,000 m.s ${ }^{1}$. The highest seismic velocity over $7,600 \mathrm{~m} \cdot \mathrm{s}^{-1}$ is typical for compact lithologies without traces of subaerial alterations.

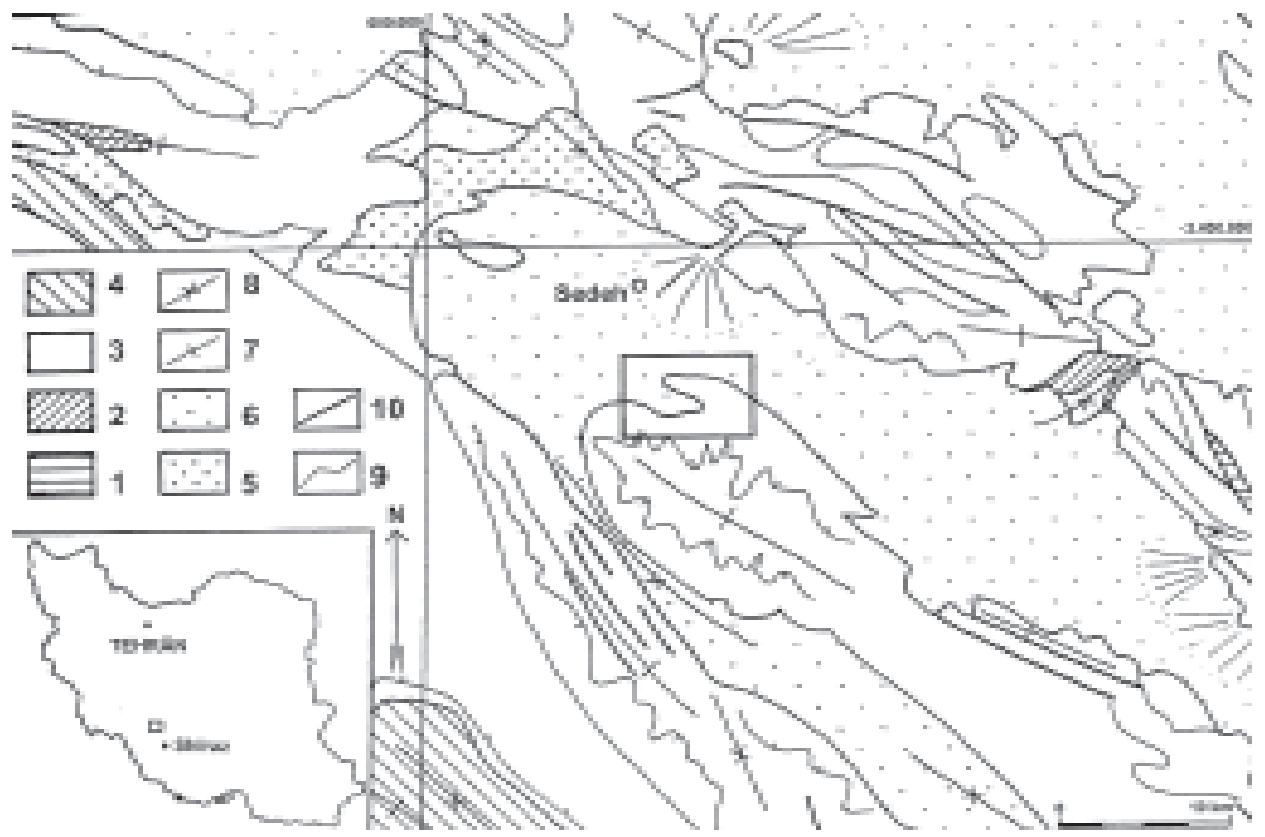

Fig. 1: Location of the Mollasadra Dam site (frame) and simplified geological map (modified after Huber 1977).

1. Triassic (Khanet Kat Fm.), 2. Jurassic (Hith-Shurmeh Fm.), 3. Cretaceous (undifferentiated), 4. Paleogene (Pabdeh-Gurpi Fm.), 5. Pliocene (Bakhtyari Fm.), 6. Quaternary (undifferentiated, with alluvial cones), 7. axis of anticline, 8. axis of syncline, 9. boundaries of lithological (lithostratigraphic) units, 10. faults. 
Cross section No. 3 (Fig. 3) was situated at the northern margin of the canyon. There are up to 3 refraction boundaries. The upper one represents the limit of Quaternary deposits (velocity of 500 to 2,000 m.s. ${ }^{-1}$ indicating local cemented conglomerates). The middle boundary represents the limit of intensively karstified zone with increased proportion of clayey limestones (velocities from 2,000 to $3,500 \mathrm{~m} \cdot \mathrm{s}^{-1}$ ). The deepest boundary corresponds to the lower limit of karstification (velocities mostly over 3,000 to 4,500 m.s. $\mathrm{m}$, the maximum thickness reaches $135 \mathrm{~m}$. Limestones with relatively low degree of fissuration show velocities over $5,000 \mathrm{~m} \cdot \mathrm{s}^{-1}$ up to $8,100 \mathrm{~m} \cdot \mathrm{s}^{-1}$.

The average value of porosity of karstified limestone has been calculated as $20 \%$.

\section{CASE STUDY 2 - KONĚPRUSY AREA}

The site is located in central Bohemia about $30 \mathrm{~km} \mathrm{SW}$ of the capital, Prague, (Fig. 4) in the SW part of the well-known geological structure of Barrandian. The geophysical exploration was carried out for revaluation of geological reserves of limestone on the Koněprusy deposit with the special aim to detect the extent, depth and character of karstification and of karst fills.

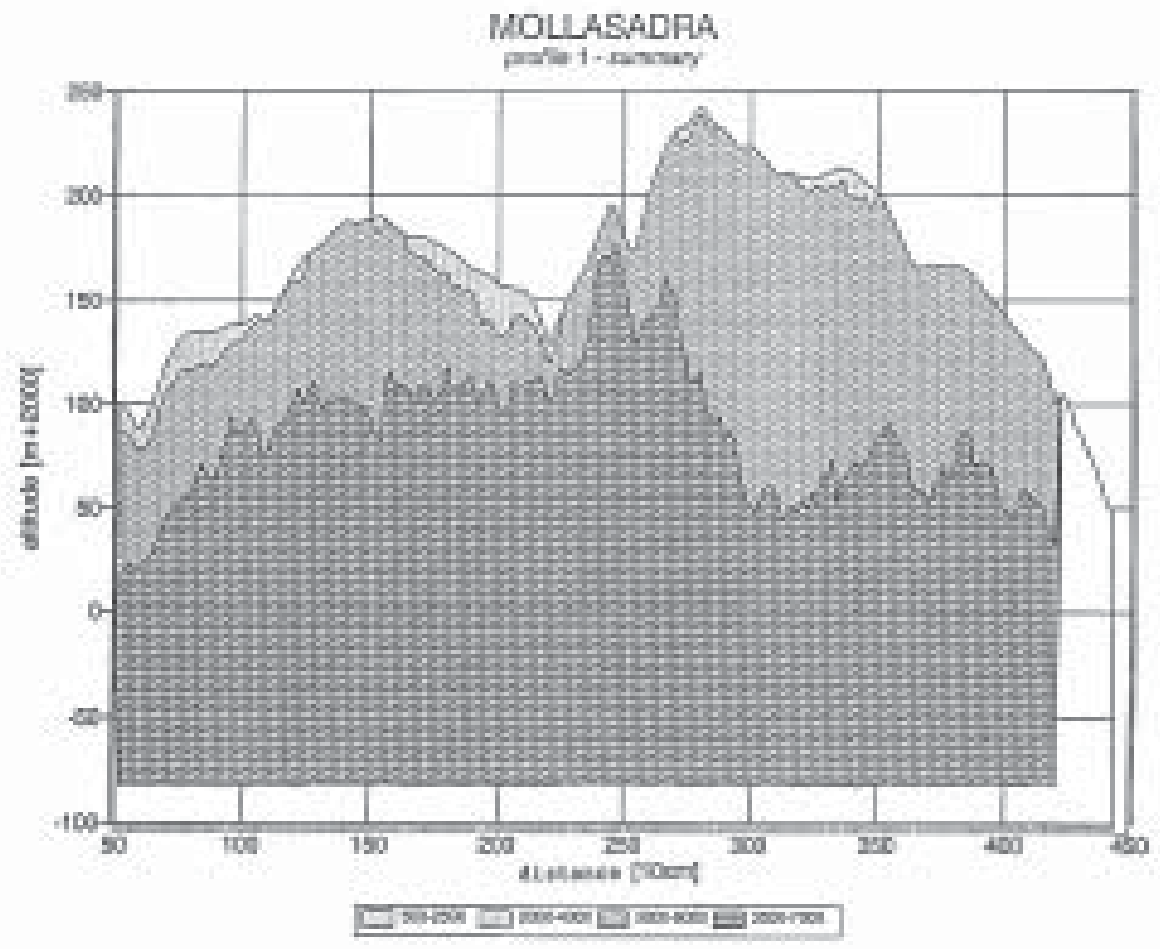

Fig. 2: Mollasadra Dam site, cross section No 1, summary of reflection seismics, (500-2500 to 2500-7000 - seismic velocities in $m \cdot s^{-1}$ ). 


\section{Geography and geology}

The Koněprusy region is situated in the southwestern closure of the Siluro-Devonian core of the Barrandian (Prague) Basin between villages of Koněprusy, Suchomasty, Vinařice and Měňany (Fig. 4). The highest summit, Zlatý kůn̆ Hill, reaches $475 \mathrm{~m}$ a.s.1., while the lowest point is at 278 $\mathrm{m}$ a.s.l. (outflow of the Suchomastský Creek).

The region, known also as the Koněprusy Devonian, is typical by special, shallow marine evolution of Lower Devonian (Pragian to Givetian) formations ( $c f$. Chlupáč et al. 1998). The prevailing part of the Lower Devonian sequence is built by massive grainstones to rudstones and, in the upper part, by reefal (bryozoan-stromatoporoid) limestones belonging to Koněprusy Limestones (Pragian) with the thickness up to $350 \mathrm{~m}$. They are underlain directly by Kotýz Limestones (fine-grained grainstones with intercalation of marsltones and fine-grained siliciclastic often with densely packed chert nodules; about $60 \mathrm{~m}$, Lochkovian). Below them, the Přídolí Formation (Přídolí, Silurian, max. $50 \mathrm{~m}$ ) also contains limestones with shaly intercalations. In the present geological configuration, the Koněprusy Limestones are overlain only partly in a narrow strip along the northern tectonic boundary of the Koněprusy Devonian by the Suchomasty Limestones (grainstones, $20 \mathrm{~m}$, uppermost Zlíchovian to Dalejan), Acanthopygae Limestones (grainstones, $20 \mathrm{~m}$, Eifelian) and by siliciclastics of the Srbsko Formation in small denudation

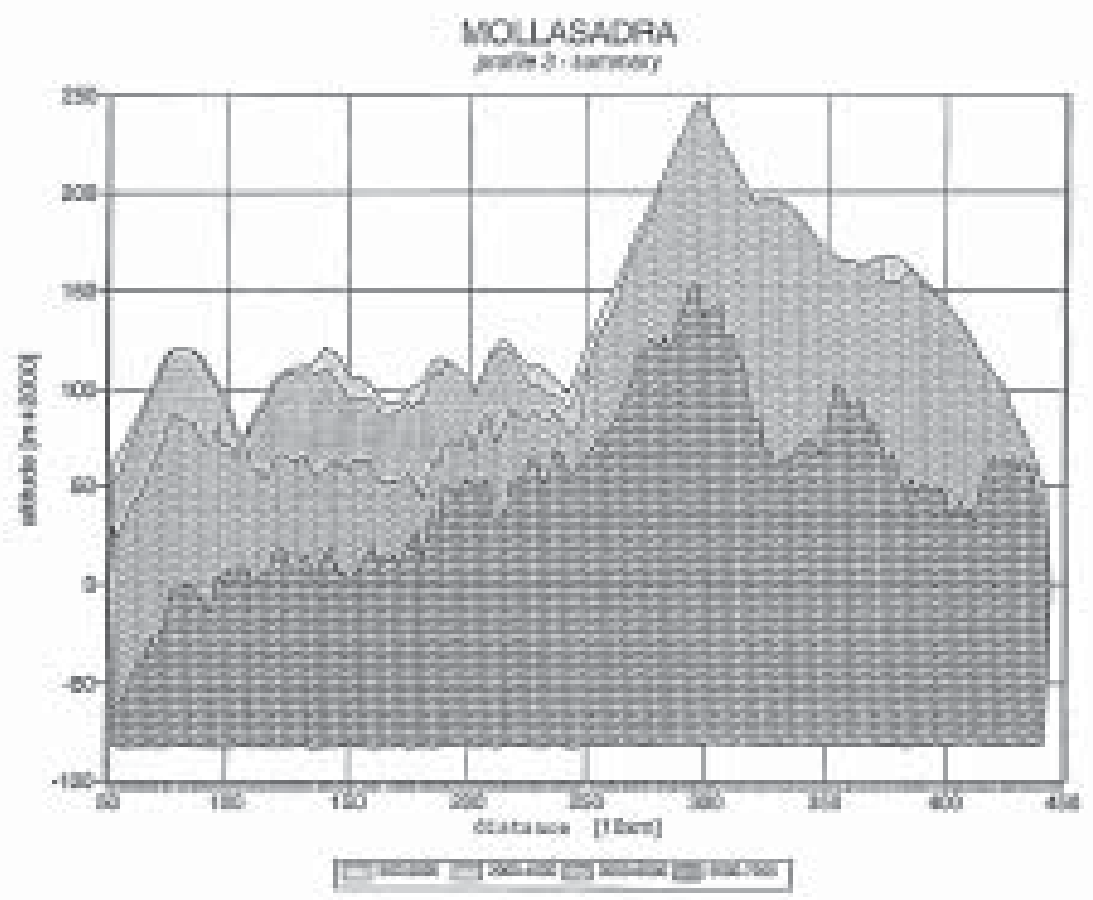

Fig. 3: Mollasadra Dam site, cross section No 1, summary of reflection seismics, (500-2500 to 2500-7000 - seismic velocities in $\mathrm{m} \cdot \mathrm{s}^{-1}$ ). 
relics (Givetian; $c f$. Chlupáč et al. 1998; Fig. 4). Koněprusy Limestones are well lithified, structurally homogeneous and brittle. They are folded into the system of open synclines and squeezed anticlines, often with overthrusts, which probably multiply the original thickness of massive limestones. The region is highly dissected by faults and fissure systems. Thick calcite veins of the N-S trend cut the whole area (Cílek, Dobeš \& •ák 1994). The Lower Devonian sequences form irregularly ovate synclinal basin-like structure isolated by underlying Silurian formations and tectonics from other occurrences of limestones. The NNE limit of the Koněprusy Devonian is formed by the major line of the Očkov Overthrust. Numerous remains of Upper Cretaceous (Cenomanian to Turonian) siliciclastics in karst forms (e.g., Kukla 1956; Cílek, Tipková \& Kvaček 1992) indicate that the region was completely covered by Upper Cretaceous platform cover, now completely eroded (Zelenka 1981). Quaternary deposits of relatively low thickness are represented by alluvial and deluvial deposits, rarely by remains of travertines.

\section{Method of seismic measurement}

The refraction seismic measurements with the length over $700 \mathrm{~m}$ are commented only, to be comparable with the Iranian site, nevertheless numerous shorter profiles were measured in a grid of 10 x 10 m on area of about 62 ha (Bárta, Hrubeš \& Beneš 1996). The seismic vawes were

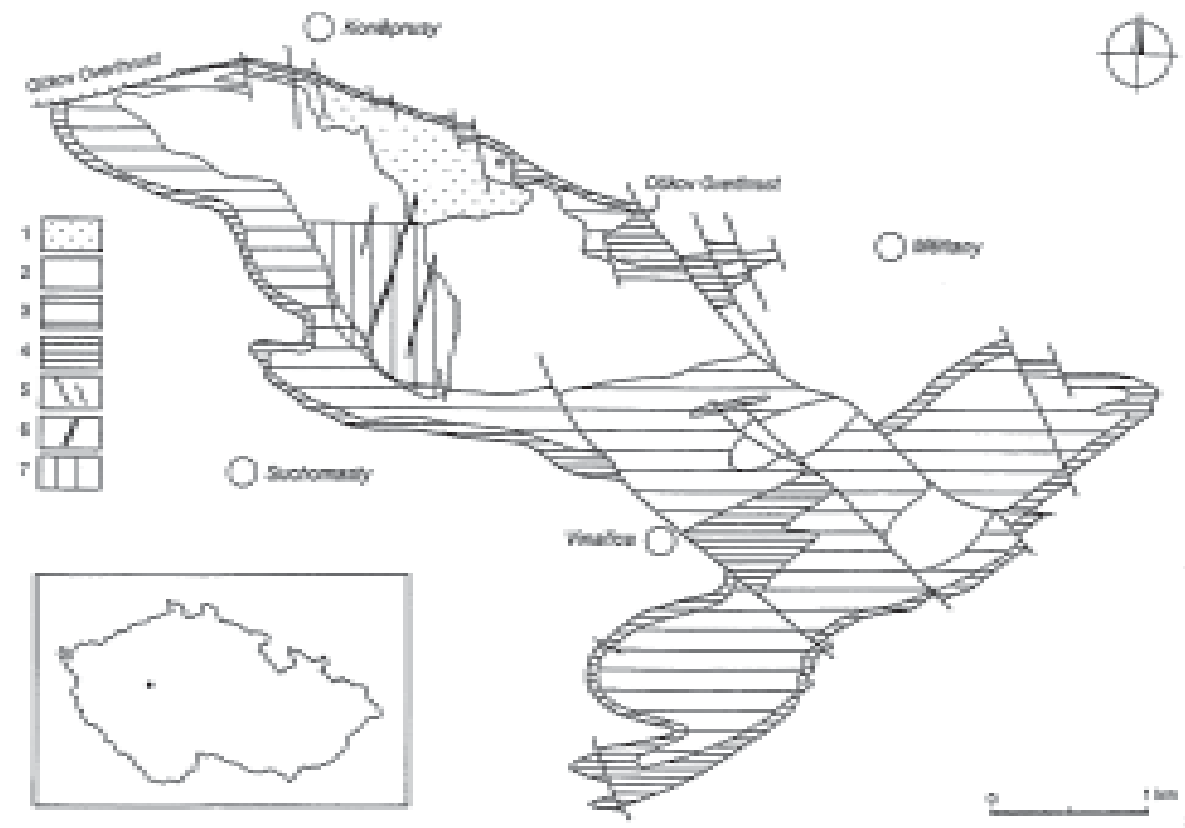

Fig. 4: Location of the Koněprusy site and simplified geological map (without Cenozic cover; completed and modified after Klein et al. 1989)

1. Srbsko Formation, Acanthopygae and Suchomasty Limestones, 2. Koněprusy limestones, 3. Kotýs Limestones, 4. Př́doli Formation, 5. faults, 6. calcite veins, 7. area of complex geophysical survey. 
induced by blasting. The distance of geophones was $15 \mathrm{~m}$. The 48 channel apparatus (OYO Seis 1600) was used. The data were processed by the $t_{0}$ method (Hagivar's method). The output is represented by cross sections with refraction boundaries and graphs of limit seismic velocities.

\section{General results of geophysical measurements}

The main seismic boundary is situated at depths of 5 to $60 \mathrm{~m}$ below the surface on most of cross sections. The boundary indicates a plane dividing environments with somewhat different physical and rock mechanic properties expressed by different seismic velocities. In areas where both Bouguer gravity anomalies and electric resistivity values are high, the seismic boundary is located in shallow depths, principally not deeper than 10-20 m. In areas characterised by some degree of mass deficit and low resistivity values, the depth of seismic boundary substantially increases following not only tectonic lines, but also zones with higher degree of karstification and karst depressions. In such places, the seismic boundary is situated up to $60 \mathrm{~m}$ below the surface. It means, that the interpreted seismic boundary follows the basal plane of epikarst (s.l.) and limits the epikarst zone from the geophysical point of view.

The comparison of gravimetry and refraction seismics can also help to distinguish the intensity of karstification in depths. Gravimetry models on a number of profiles indicate deep karstification
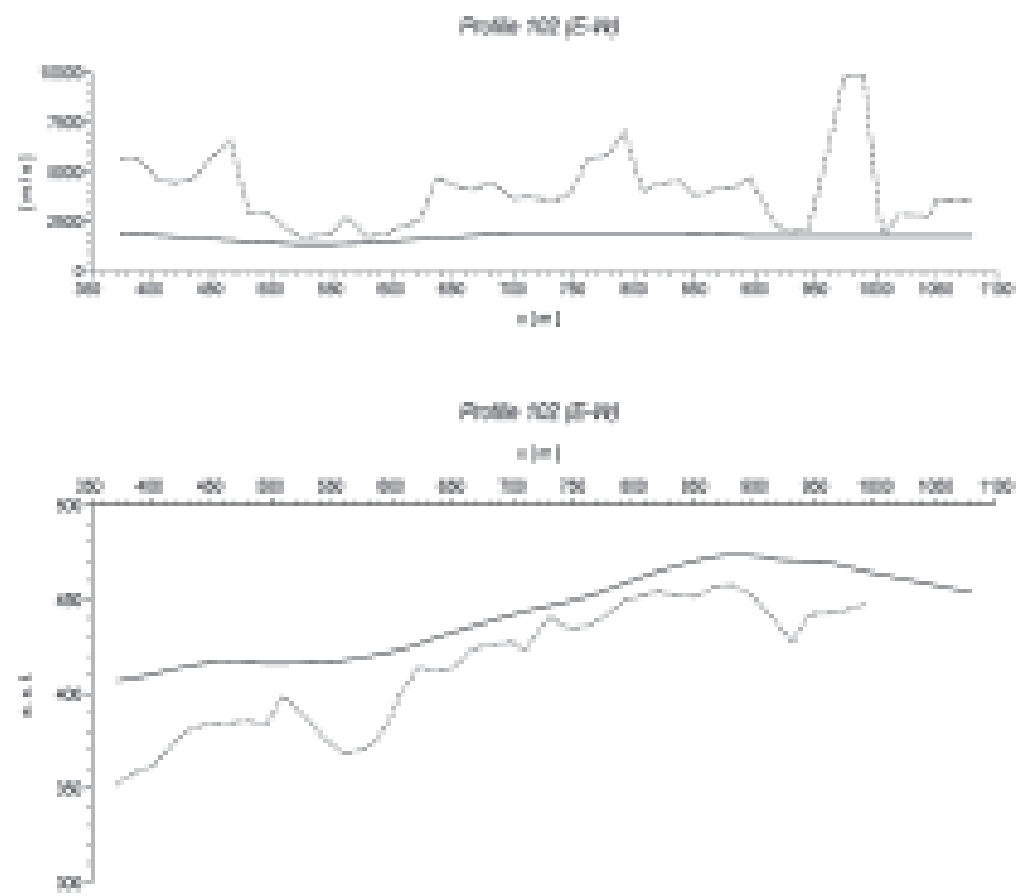

Fig. 5: Koněprusy site, cross section No. 50 (N-S), summary of reflection seismics, seismic velocities (upper graph) and interpretation of seismic boundary (lower graph). 
over $70 \mathrm{~m}$ up to $95 \mathrm{~m}$, while seismic boundaries are situated at about $40 \mathrm{~m}$. The seismic boundary then represents limit depth of intensive karstification with less karstified rocks below this limit. Along dominant number of geophysical profiles, there was identified a good agreement of resistivity and seismic measurements.

On some shorter profiles, two seismic boundaries were interpreted. The upper one is situated not deeper than $25 \mathrm{~m}$ below the surface and the lower one lies at $30-70 \mathrm{~m}$ below the surface. This boundary can express zone with different proportion of inhomogeneities caused both by different degree of karstification and/or density of tectonic lines.

\section{Description of typical cross sections}

Cross section No. 50 (N-S). One seismic boundary was interpreted. It represents the zone of karstification with mean seismic velocity of 1,000 to $2,500 \mathrm{~m} \cdot \mathrm{s}^{-1}$. Relatively undisturbed limestones, except for local faults and karst depression, show velocities over 4,000 m.s. detected velocity reached $7,500 \mathrm{~m} \cdot \mathrm{s}^{-1}$. The average thickness of karstified zone is $18.5 \mathrm{~m}$ and maximum depth reaches $40 \mathrm{~m}$, the minimum depths is less than $5 \mathrm{~m}$ !

Cross section No. 102 (W-E). One seismic boundary was interpreted. It represents the zone of
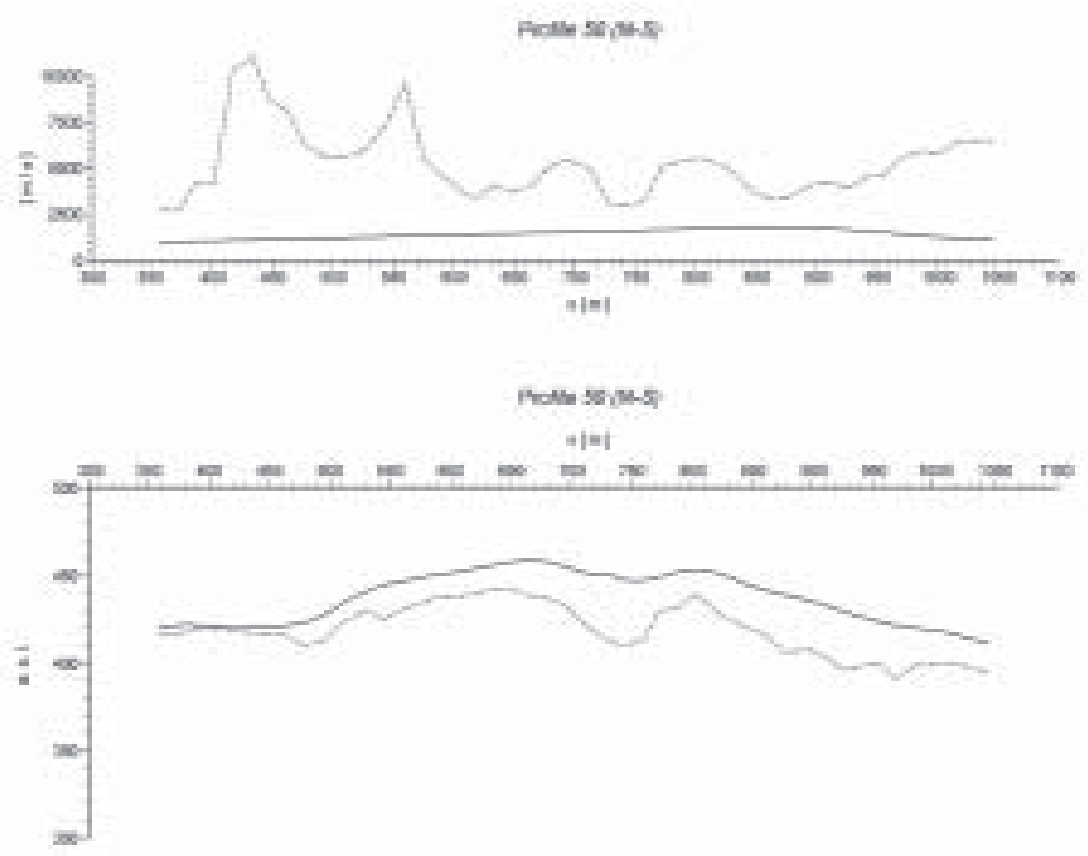

Fig. 6: Koněprusy site, cross section No. 102 (W-E), summary of reflection seismics, seismic velocities (upper graph) and interpretation of seismic boundary (lower graph). 
karstification with mean seismic velocity of 1,000 to $2,500 \mathrm{~m} \cdot \mathrm{s}^{-1}$. Relatively undisturbed limestones, except for local faults and karst depression, show velocities over 4,000 m. $\mathrm{s}^{-1}$. The maximum detected velocity reached $7,300 \mathrm{~m} \cdot \mathrm{s}^{-1}$. The average thickness of karstified zone is $30 \mathrm{~m}$ and maximum depth reaches $52 \mathrm{~m}$.

The average value of porosity of karstified limestone has been calculated to about $18 \%$.

\section{DISCUSSION}

Both sites differ substantially by geological and geomorphological positions. This fact strongly influences the physical properties of rocks in nearsurface karstified - epikarst - zone.

\section{Porosity}

The intensity of karstification in both sites expressed as calculated porosity of $20 \%$ for Mollasadra site and $18 \%$ for Koněprusy area is comparable. Nevertheless the volume of preserved primary porosity of various kinds differs substantially.

The Cretaceous limestone sequences (wackestones to packstones) of the Mollasadra site underwent only medium stage of diagenesis with preserved primary porosity both of inter- and intraparticle type (sensu Moore 2001). Some parts of the sequence were reported to have chalky character (Huber 1977; Setudehnia 1977). The karstification products are represented by karren systems and corroded bedding planes continuing to the depth into network of small vugs and corroded fissures with some larger cavities (diameter of about $1 \mathrm{~m}$ ).

On the contrary, Lower Devonian Koněprusy limestones (mostly grainstones) are highly lithified and cemented with dominant syntaxial overgrowths and porosity of only $2.01 \%$, which is mostly secondary in nature (Bosák et al. 2001). Karstification in nearsurface zone is characterised by minor karren development (shallow subcutaneous karren), karstified fissures, sometimes with sediment fill, small karst channels (mostly up to $0.5 \mathrm{~m}$ in diameter), rare sinkhole-like forms and extensive karst depression with sedimentary fill - results of uppermost Cretaceous to Miocene (?) hydrothermal karstification (Bosák 1998, 2000, 2001). The karstification products are sharply limited in the respect to the host rock.

\section{Vertical character of epikarst}

The intensity of karstification on Mollasadra site decreases with the depth only gradually. On the Koněprusy site, the gradient is expressive, except of principal fault lines/fissured zones. The feature is clearly caused by completely different geological and lithological structure on both sites.

The Mollasadra site is situated in squeezed asymmetric anticline with steeply dipping flanks. Geophysical measurements detected numerous normal faults parallel to slightly oblique to anticline axis, corresponding to older geological maps from the area (Huber 1977). Such faults, especially in upper part of anticlinal flanks, have sinking tendency along dip angle of flanks caused by a relaxation after main tectonic stress (Jaroš in Bosák et al. 1998). More, interbed slips resulting from geometry of fold formation can play also a substantial role in origin of weakened zones in the massif. Water can penetrate limestone sequences along such inhomogeneities more easily and into more substantial depths. Figures 2 and 3 illustrate well the anticlinal geology with reliefforming massive limestones in the centre and less resistant lithologies with clayey/marly 
intercalations combined with faults in anticline flanks. The evolution of the karstified nearsurface zone can be linked here with gradual continuous uplift during more or less single orogenic phase.

The geological structure of the Konéprusy site, on the other hand, is characterised by shallow synclinal structure with strata dip from 2 to $\max .15^{\circ}$. The limestone massif is lithologically relatively uniform, with no different interbeds. The syncline is highly dissected by faults and fissure zones, with dominant N-S and WNW-ESE trends, and also abundant lines of NW-SE and NE-SW trends. The N-S trends are followed by several zones of thick hydrothermal calcite veins (Variscan and ?Tertiary in age), commonly 1-5 m thick. The W-E trends are followed by several generations of neptunic dykes (Pragian to Givetian age), which are commonly polycyclic and up to $20 \mathrm{~m}$ thick. Both calcite veins and neptunic dykes represent the zones of preferential routes for deep circulation of meteoric waters (Cílek, •ák \& Dobeš 1994). The substantial depth of karstification was proved by geophysics and boreholes especially on intersection of main fault/ fissure lines/zones where ovate karst depression as deep as $85 \mathrm{~m}$ also developed (Bosák 2000) and karstification reached deeply to underlying formations (Bárta, Hrubec \& Beneš 1996). The limestone massif was intensively affected also by penetration of hydrothermal solutions along principal structural zones (Bosák 1998, 2001) causing intergranular corrosion (granular disaggregation of Dżułyński \& Kubicz 1971) of grainstones up to loose residuum composed of individual allochems (Cílek, Bosák \& Bednářová 1995) well visible in boreholes and on quarry walls. The evolution of relief in the Koněprusy area was complex, polygenetic and polycyclic (Bosák 1997a) starting with regression of Upper Cretaceous sea and denudation of thick siliciclastic cover of Cenomanian to Santonian age. There are developed several planation surfaces (Paleogene) and series of terraces (early Miocene to Pleistocene) indicating the start of entrenchment of valley network as early as during Paleogene (Bosák 1997a). The youngest phase of backward erosion linked with late Pleistocene terraces is relatively weak and dominantly follows tectonic lines (Lysenko 1987). Each phase contributed to the evolution of epikarst with the respect to present paleoenvironmental conditions. The long and complex evolution of epikarst could cause very uneven basal plane of the zone expressed on Figures 5 and 6 as seismic boundaries. Both figures indicate no relation to present-day morphology. Direct geological observations in open quarries indicate, that the epikarst zone can be completely missing on gentle slopes covered by slope deposits (scree). This means, that erosional processes on slopes can contribute to the diminution of epikarst thickness.

\section{Vertical extent of epikarst}

The vertical extent of epikarst zone indicated by geophysical methods differs on both sites. On the Mollasadra site, the epikarst reaches the depth of 176 m, while on Koněprusy site its thickness is only $60 \mathrm{~m}$., i.e. approx. one third. The reason was described above, i.e. completely different geological structure of both sites, especially strata dips, and morphology.

The character of Mollasadra site results from location within young mountains typical by substantial altitude differences in anticlinal mountain ridge (more than 1,000 m). There are expressive deep disrupted zones resulting from relaxation of tectonic stress after distinct and young orogenic phase.

The Konéprusy site with old orogenic history followed by intensive platform evolution (planation predominated, $c f$. Bosák 1997b) has only slight total vertical difference (about $180 \mathrm{~m}$ ). 
Therefore, the zone of release of residual stress in the rocky massif is also relatively shallow. This fact influences the density of fine fissures and their vertical extent in nearsurface zone. The diminution in density of fissures with the depth is well observable on more than $150 \mathrm{~m}$ high walls of open quarries.

\section{CONCLUSIONS}

The complex of geophysical methods based especially on refraction seismics with complementary electrical resistivity, electrical sounding and gravimetry represents a useful tool for detection of nearsurface zone in limestone areas. The zone is characterised by low seismic velocities ranging from commonly 1,000 to $2,500 \mathrm{~m} \cdot \mathrm{s}^{-1}$, max. up to $4,000 \mathrm{~m} \cdot \mathrm{s}^{-1}$. Such zone is limited by seismic boundary on which the seismic velocities rapidly grow over $4,000 \mathrm{~m} . \mathrm{s}^{-1}$. The interpreted seismic boundaries follow the basal plane of epikarst (s.l.) and limit the epikarst zone from the view of its physical properties.

Two completely different geological settings were studied. The Mollasadra site in Islamic Republic of Iran is situated in a young orogenic belt (Zagros Mts.) composed of anticline mountain ranges with distinct altitude differences. Less diagenetically mature Upper Cretaceous limestones contain some clayey to marly intercalations. The epikarst zone detected by geophysics is up to nearly $180 \mathrm{~m}$ deep following steep strata dip and longitudinal steep normal faults. The Koněprusy site in the Czech Republic is situated on consolidated epi-Variscan platform. Lower Devonian limestones are highly lithified, forming a flat syncline. Altitude differences are low. Epikarst zone is 5 to $60 \mathrm{~m}$ deep.

It seems that the thickness of geophysically defined epikarst zone depends on relief, which influences also release of relict tectonic stress in nearsurface zone, lithology of rocks, and volume of porosity reflecting intensity of lithification (diagenesis) and later geomorphic processes.

\section{ACKNOWLEDGEMENTS}

We thank representatives of the Velkolom Čertovy schody, a.s. and Českomoravský cement, a.s. (Heidelberger Cement Group) for permission to utilise data obtained during the geological exploration of the Koněprusy site. The study was compiled within the Research Plan of the Institute of Geology of the Academy of Sciences of the Czech Republic (No. CEZ Z 03-013-912). Figures were digitised and partly redrawn by Mrs. Jana Rajlichová (Inst. Geol. AS CR).

\section{REFERENCES}

Bárta J., Hrubec J. \& Beneš V., 1996: Results of geophysical measurements (in Czech). - MS, Final report, G-Impuls Ltd.: 1-56. Praha.

Bosák P., 1997a: Notes to the morphology of broader vicinity of Koněprusy village (Czech Karst, Czech Republic; in Czech). - Český kras (Beroun), 23: 19-32.

Bosák P., 1997b: Paleokarst of the Bohemian Massif in the Czech Republic: an overwiev and synthesis. - International Journal of Speleology, 24, 1-4 (1995): 3-39.

Bosák P., 1998: The evolution of karst and caves in the Koněprusy region (Bohemian Karst, Czech Republic), Part II: Hydrothermal paleokarst. Acta Carsologica, 27/2, 3: 41-61. Ljubljana. 
Bosák P., 2000: The evolution of karst and caves in the Koněprusy region (Bohemian Karst, Czech Republic), part III: Collapse structures. - Acta Carsologica, 29/2, 2: 35-50. Ljubljana.

Bosák P., 2001: Hydrothermal speleogenesis in the Koneprusy area (Bohemian Karst, Czech Republic). - Proceedings, $13^{\text {th }}$ International Speleological Congress, $4^{\text {th }}$ Speleological Congress of Latin America and the Carribean, 26 $6^{\text {th }}$ Brazilian Congress of Speleology, Brasilia, July 15-22, 2001: 120.

Bosák P., Jaroš J., Spudil J., Sulovský P. \& Václavek V., 1998: Salt Plugs in the Eastern Zagros, Iran: Results of Regional Geological Reconnaisance. - Geolines (Praha), 7: 1-178.

Bosák P., Slavík L., Hladil J., Trčková J. \& •ivor R., 2001: Report on research for the Velkolom Čertovy schody a.s. (geological part) in 2000. - MS, Institute of Geology AS CR: 1-69. Praha.

Chlupáč I., Havlíček V., Křŕ J., Kukal Z. \& Štorch P. (Eds.), 1998: Palaeozoic of the Barrandian (Cambrian-Devonian). - Vydavatelství Českého geologického ústavu: 1-181. Praha.

Cílek V., Bosák P. \& Bednářová J., 1995: Intergranular corrosion, infiltrational kaolinization and epigenetically reddened limestones of the Bohemian Karst, and their influence on karst morphology. - Studia Carsologica, 6: 131-150. Brno.

Cílek V., Dobeš P. \& •ák K., 1994: Formation conditions of calcite veins in the quarry "V Kozle (Hostim I, Alkazar)" in the Bohemian Karst. - Journal Czech geological Society, 39, 4: 313-318.

Cílek V., •ák K. \& Dobeš P., 1994: Hydrothermal process and karst in Czechia (in Czech). Speleo (Praha), 17: 26-30.

Cílek V., Tipková J. \& Kvaček Z., 1992: New finds of Cretaceous rocks in the Koněprusy area and the Petrbok's stage of the Koukolová hora (in Czech). - Český kras (Beroun), 17: 35 39.

Dżułyński S. \& Kubicz A., 1971: Recrystallized and disaggregated limestones in the Triassic of Silesia. - Rocznik Polskiego Towarzystwa Geologicznego, 41: 521-530.

Huber H., 1977: Geological Map of Iran Sheet No. 5 South-Central Iran. - National Iranian Oil Company. Tehran.

Klein V. et al., 1989: Geological map 1:25,000, sheet Králův Dvůr. - Ústřední ústav geologický. Praha.

Kukla J., 1956: Cretaceous sediments in Koněprusy near Beroun (in Czech). - Časopis pro mineralogii a geologii, 1, 1: 24-30. Praha.

Lysenko V., 1987: Utilisation of remote sensing on example of the Koněprusy area (in Czech). Český kras (Beroun), 13: 29-35.

Moore C.H., 2001: Carbonate Reservoirs. Porosity Evolution and Diagenesis in a Sequence Stratigraphic Framework. - Developments in Sedimentology, 55: 1- 444. Elsevier, Amsterdam.

Nowroozi A.A., 1972: Focal mechanism of earthquakes in Persia, Turkey, West Pakistan, and Afghanistan and plate tectonics of the Middle East. - Bulletin Seismological Society America, 62, 3: 823-850.

Setudehnia A.O., 1977: Stratigraphic lexicon of Iran, Part II, South-west Iran. $2^{\text {nd }}$ Ed. (reprint). Geological Survey Iran, Report, 18: 285-376. Teheran.

Zelenka P., 1981: Occurrences of Upper Cretaceous sediments at the territory of the Bohemian Karst (in Czech). - Český kras (Beroun), 6:29-35. 